\author{
Alfisyahrina Hapsery, \\ Sari Cahyaningtias, \\ Edy Sulistiyawan \\ Universitas PGRI Adi Buana Surabaya. \\ Jalan Dukuh Menanggal XII, Dukuh \\ Menanggal, Kecamatan Gayungan, \\ Surabaya, \\ Jawa Timur 60234 \\ Email: alfisyahrina@unipasby.ac.id
}

\section{Implementasi Data Kependudukan Berbasis Statistik dan Excel}

\author{
DOI: 10.18196/berdikari.v9i2.9122
}

\begin{abstract}
The digital era demands that all components of institutional infrastructures be able to adapt for effective and efficient activities' management. Gedangan Village, Sedayu, Gresik, as a government institution, must be able to adapt to the development of the digital age as well. However, the lack of knowledge and skills of village officials regarding information technology has become an overwhelming obstacle. The purpose of the community service program in Gedangan village was to increase the capacity of village government officials in the mastery and application of statistical and excel-based information technology. The methods applied in achieving the objectives were lectures and practicals. The results of the program showed improvement of knowledge and skills of the village apparatus in the analysis and presentation of population data based on statistics and excel. The increased capacity was indicated by the ability of the improvement participants to answer correctly from the 7 (seven) questions. All participants were able to answer correctly from 5 questions reaching 100\%, 1 question of 83.3\%, and the last question with $66.67 \%$.

Keywords: Population Data, Ms. Excel, Descriptive Statistics, Data Visualization.
\end{abstract}

\title{
ABSTRAK
}

Era digital menuntut semua komponen infrastruktur kelembagaan harus mampu beradaptasi agar pengelolaan aktivitasnya efektif dan efisien. Desa Gedangan, Sedayu, Gresik sebagai Lembaga pemerintahan harus mampu menyesuaikan perkembangan era digital juga. Namun, minimnya pengetahuan dan ketrampilan aparatur desa akan teknologi informasi menjadi kendala utama. Tujuan program pengabdian kepada masyarakat di desa Gedangan, yaitu untuk meningkatkan kapasitas aparatur pemerintah desa dalam penguasaan dan penerapan teknologi informasi berbasis statistik dan excel. Metode yang diterapkan dalam mencapai tujuan, yakni ceramah-tutorial dan praktik. Hasil program yang diperoleh yaitu pengetahuan dan ketrampilan aparatur desa meningkat dalam analisis dan penyajian data kependudukan berbasis statistic dan excel. Peningkatan kapasitas ditunjukkan oleh kemampuan peserta menjawab dengan benar dari 7 (tujuh) pertanyaan yang diberikan. Semua peserta dapat menjawab benar dari 5 pertanyaan mencapai 100\%, 1 pertanyaan 83,3\%, dan 1 pertanyaan diperoleh 66,67\%.

Kata Kunci: Data Populasi, Ms. Excel, Statistik Deskriptif, Visualisasi Data, 


\section{PENDAHULUAN}

Pengabdian Masyarakat merupakan suatu kegiatan bagi dosen dalam memenuhi Tri Dharma Perguruan Tinggi yang diatur dalam UUD 12 Tahun 2012. Begitu pula bagi Dosen Prodi Statistika Universitas PGRI Adi Buana Surabaya yang melaksanakan Pengabdian dalam suatu bentuk pelatihan. Pelatihan disesuaikan berdasarkan kebutuhan para peserta di desa tempat pengabdian dilaksanakan. Pada pengabdian kali ini, Dosen Prodi Statistika mendapatkan kesempatan untuk melaksanakan pelatihan di Desa Gedangan, Kec. Sedayu, Kab. Gresik. Kordinasi dilakukan selama beberapa tahap, kordinasi pertama kali dilakukan dengan observasi ke lokasi secara langsung. Permasalahan penduduk Desa Gedangan adalah kurangnya keterampilan para perangkat desa dan pengelola Bumdes dalam menvisualisasi data dengan tampilan yang menarik dan memberikan informasi yang bermanfaat. Selain itu, kurangnya keterampilan para perangkat desa dan pengelola bumdes dalam mengoperasikan fungsi-fungsi manajeman data menggunakan Microsoft Excel (Ms. Excel) sebagai me"ia yang sering digunakan untuk memvisualisasikan data. Fungsi manajeman dasar yang diperlukan seperti penggunaan pivot table untuk mempermudah mengklasifikasikan data. Dengan menggunakan pivot table, tentunya dapat mempermudah dalam mengolah seluruh data desa.

Visualisasi data merupakan bagian terkecil dari statistika deskriptif. Kemampuan visualisasi data ini berkaitan dengan kemampuan seseorang melakukan pengolahan untuk membuat informasi seringkas mungkin (Hidayat, W. \& Rahardjoo, N, 2014). Visualisasi dapat mempermudah dalam mendiagnosis suatu keadaan dari suatu data, dalam hal ini khususnya data kependudukan Desa Gedangan. Pelatihan ini juga mengajarkan keterampilan dasar yang harus diketahui sebelum visualisasi data yaitu statistika inferensia yang nanti akan membantu para perangkat desa untuk dapat membedakan mana data yang dapat divisualisasikan dan mana data yang hanya dapat dijelaskan dengan inferensia. Peran statistika inferensia untuk membedakan sampel dan populasi serta proses penarikan suatu kesimpulan (Bhattacharyya \& Richard, 2009).

Dalam pengolahan data sebagai dasar eksplorasi dan visualisasi baik dengan pivot penting bagi seorang analis untuk mengetahui skala data. Mengingat bahwa jumlah data di desa ini tidak sedikit bahkan jumlahnya bisa dikategorikan melebihi ratusan data warga desa dan informasi data yang masih belum ter-update. Menurut Guerrero (2019), terdapat beberapa jenis skala data secara umum, yaitu nominal, ordinal, interval, dan rasio. Dari keseluruhan skala data, keempatnya dapat disajikan dalam bentuk visualisasi data. Mayoritas data desa berskala nominal dan ordinal sehingga lebih banyak menggunakan bentuk visualisasi yaitu grafik. Heiberger \& Holland (2015) menuliskan 
bahwa visualisasi data tidak hanya dengan diagram batang atau digambarkan dengan diagram lingkaran. Selain itu, terdapat beragam jenis visualisasi data dengan berbagai skala data, seperti scatter plot, bubble chart, dan boxplot. Jenis visualisasi data ini yang akan diajarkan pada bumdes dan perangkat Desa Gedangan.

Kerangka teoretis dari pelatihan yang direncanakan ini yaitu menjelaskan secara teori tentang dasar suatu data hingga visualisasi yang sesuai dengan tipe data. Pengabdian ini disusun dengan konsep workshop. Para peserta akan dilatih penggunaan excel, kemudian dilakukan pratikum dari data riil (Panjaitan \& Firmansyah, 2018). Evaluasi dari pelatihan ini dapat dilakukan secara langsung dengan melihat hasil pengolahan di laptop peserta masing-masing dan pertanyaan yang dijawab oleh peserta setelah pelatihan selesai. Apabila terdapat hasil yang kurang tepat, pelatih yakni dosen prodi statistika akan memberikan arahan yang sesuai. Pelatihan Manajemen Data Kependudukan di Desa Gedangan ini didasarkan pada perlunya perkembangan penguasaan teknologi informasi oleh berbagai pihak dan tidak terkecuali lembaga pemerintahan tingkat desa. Pengumpulan data-data kependudukan, data sumber daya, dan potensi desa membutuhkan pengelolaan data yang optimal dan penyajian yang informatif dan tepat. Oleh karena itu, kegiatan pelatihan yang dilakukan di Desa Gedangan ini bertujuan meningkatkan kemampuan aparatur desa dalam mengolah data kependudukan.

\section{METODE PELAKSANAAN}

Langkah pelaksanaan kegiatan adalah melakukan koordinasi dengan mitra tempat diselenggarakannya pelatihan hingga koordinasi sampai pelatihan terlaksana dan penutupan pada tanggal 27 Januari 2020 hingga 13 Februari 2020. Suatu kegiatan pasti berawal dari perencanaan hingga target yang dihasilkan. Sama halnya dengan program pengabdian yang dilaksanakan oleh dosen statistika Universitas PGRI, berawal dari perencanaan hingga target yang ingin dicapai yaitu hasil post-test menunjukkan tingkat pemahaman peserta. Rencana awal bermula dari permasalahan yang dihadapi perangkat Desa Gedangan yaitu minimnya pengetahuan pengolahan data untuk pengolahan data kependudukan. Dengan adanya program pengabdian ini, pengabdi berharap perangkat desa dan bumdes akan lebih terampil dalam mengeksplorasikan data dan memahami langkah yang harus dilakukan untuk mengolah data. Pelatihan ini diberikan dengan bantuan alat analisis yaitu Ms. Excel khususnya pivot dan pembuatan grafik. Tahapan dalam pelatihan ini yaitu ceramah (pengenalan dasar), workshop, dan simulasi. Peserta dari kegiatan pelatihan dalam rangka pengabdian kepada masyarakat ini berjumlah 13 orang. Peserta pelatihan juga berasal dari guru program PAUD di Desa Gedangan. Secara 
garis besar, prosedur pelatihan pada pengabdian di Desa Gedangan adalah sebagai berikut.

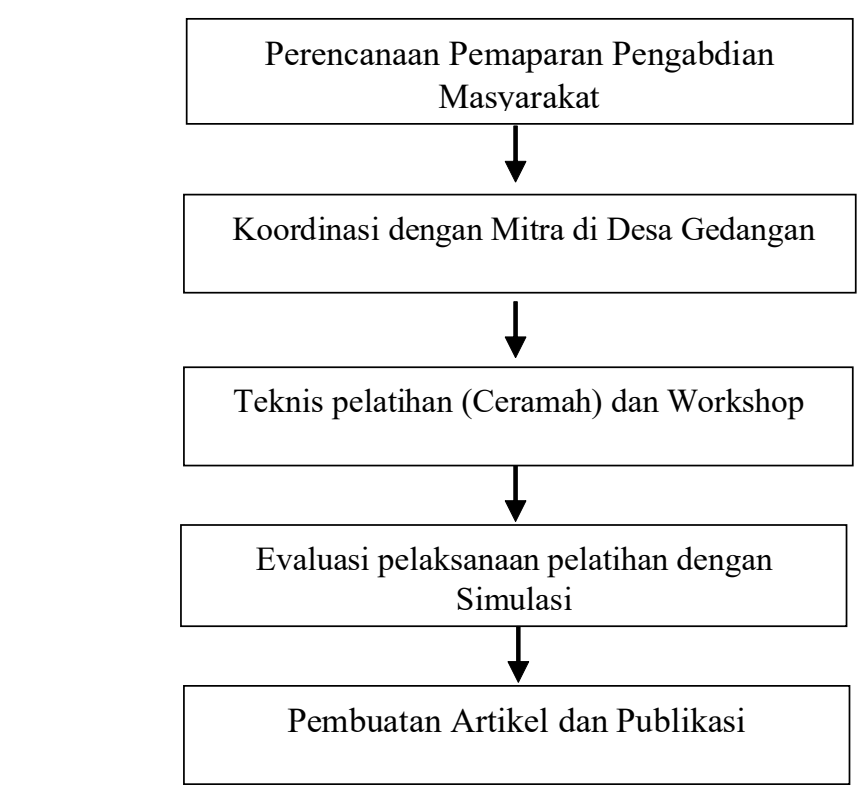

Gambar 1. Diagram Alur Kagiatan Pengabdian Masyarakat di Desa Gedangan

Evaluasi dari pelatihan ini dapat dilihat dari hasil simulasi dari metode ceramah dengan soal yang dijwab oleh peserta, sedangkan untuk evaluasi dari metode workshop yaitu dengan melihat secara langsung hasil grafik yang dihasilkan peserta.

\section{HASIL DAN PEMBAHASAN}

Kegiatan PPM ini telah dilaksanakan oleh Tim Pengabdian Program Studi Statistika Universitas PGRI Adi Buana yang bekerja sama dengan Kepala Desa Gedangan Kecamatan Sidayu Kabupaten Gresik (Muhammad Sholih, S.Sos., M.Sos). Kegiatan PPM ini dihadiri oleh 13 peserta yang terdiri atas perangkat desa, guru PAUD, dan anggota bumdes di Desa Gedangan. Pelaksanaan PPM ini bertempat di Balai Desa Gedangan bertahap dimulai pada tanggal 24 Februari. Kedatangan peserta tepat waktu yaitu sepuluh menit sebelum kegiatan dimulai. Kegiatan dilaksanakan dengan tertib dan lancar seperti yang terlihat pada Gambar 2 .

Dalam pelaksanaan pelatihan pada kegiatan pengabdian masyarakat ini, peserta pelatihan diberi dasar pengetahuan tentang data mulai dari jenis data hingga perbedaan statistika deskriptif yang digunakan untuk visualisasi dan statistika inferensia yang mendukung. Pemaparan materi dan contoh yang sesuai dilakukan langsung menggunakan contoh data kependudukan Desa Gedangan yang sebelumnya telah dikordinasikan seperti pada Tabel 1 


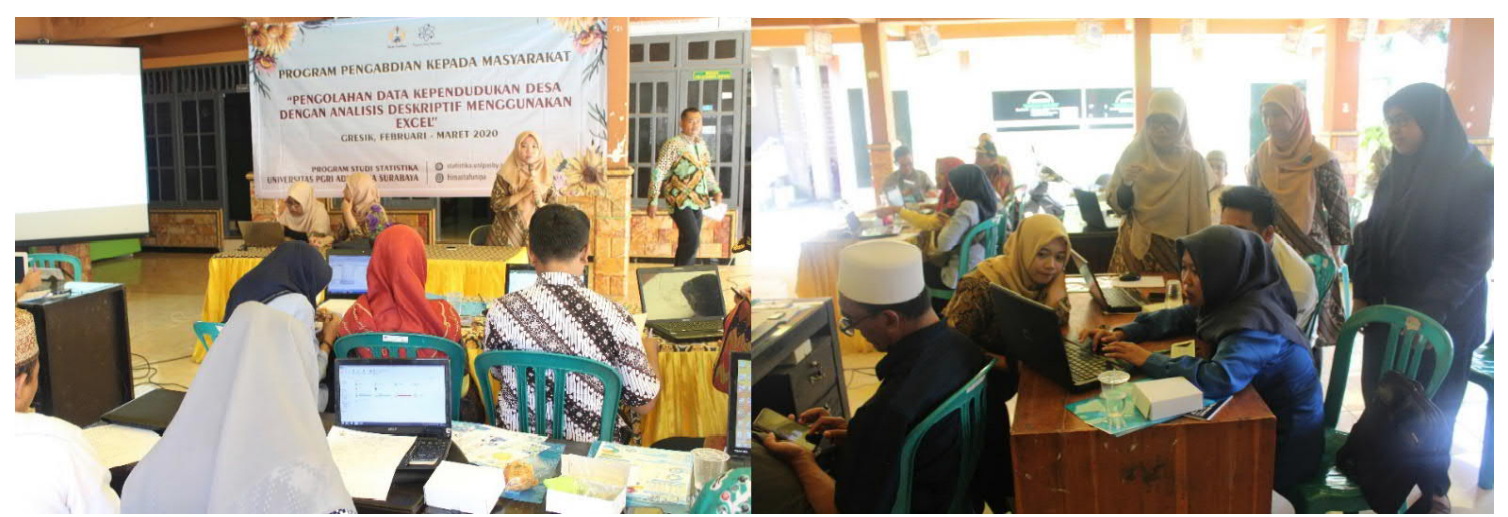

Gambar 2. Penyampaian Materi Mengenai Jenis-Jenis Chart dan Workshop Visualisasi Data Kependudukan

Tabel 1. Penyampaian Materi Mengenai Jenis-Jenis Chart dan Workshop Visualisasi Data Kependudukan Potensi Sumber Daya Manusia

\begin{tabular}{ll}
\hline Jenis & Jumlah \\
\hline Laki - laki & 1264 orang \\
\hline Perempuan & 1290 orang \\
\hline Total & 2554 orang \\
\hline Kepala Keluarga & $656 \mathrm{KK}$ \\
\hline Kepadatan Penduduk & $1.811,35$ per KM \\
\hline
\end{tabular}

Tabel 1 adalah tabel yang digunakan pada Profil desa potensi 2019 Desa Gedangan. Materi yang diajarkan adalah proses mengolah data, salah satu contohnya adalah tabel berikut yang dapat diolah menjadi grafik yang menarik. Selain itu, dalam satu tabel sebaiknya dapat menyesuaikan seperti jumlah kepala keluarga dan kepadatan penduduk. Jumlah kepala keluarga dan kepadatan penduduk sebaiknya tidak dalam tabel yang sama, begitupun dengan jumlah total laki-laki dan perempuan. Tampilan tabel juga kurang menarik minat pembaca, khususnya di era industri 4.0 seperti saat ini dengan informasi yang banyak digambarkan dalam bentuk grafik. Tabel 1 dapat dibentuk dalam sebuah grafik seperti pada Gambar 3. Grafik yang sesuai yaitu diagram lingkaran yang menunjukkan jumlah penduduk laki-laki dan perempuan dalam hitungan persentase. Tujuan penggunaan grafik ini untuk mempermudah dalam penyampaian informasi. 
Laki - laki
Perempuan

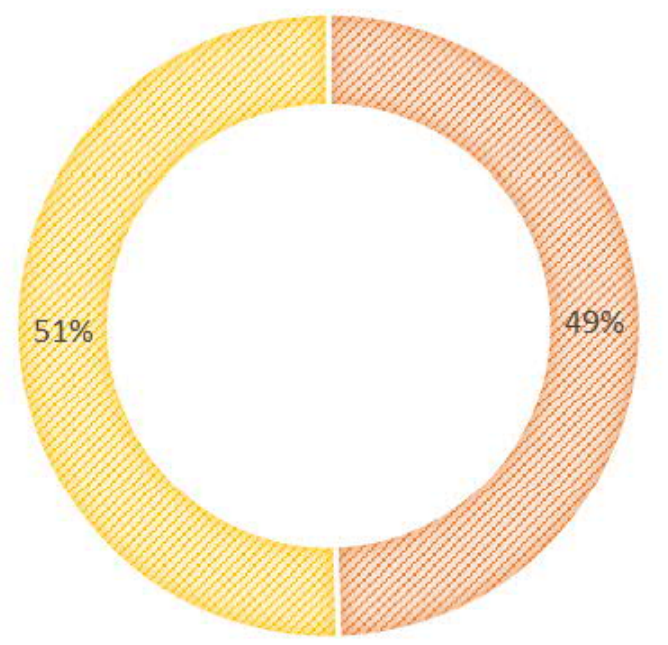

Gambar 3. Diagram Lingkaran Jumlah Penduduk Desa Gedangan

Selain diagram batang, data profil desa juga bisa dieksplorasi dengan menginformasikan mata pencaharian pokok penduduk desa yang dibedakan berdasarkan jenis kelamin seperti pada Gambar 4 berikut.

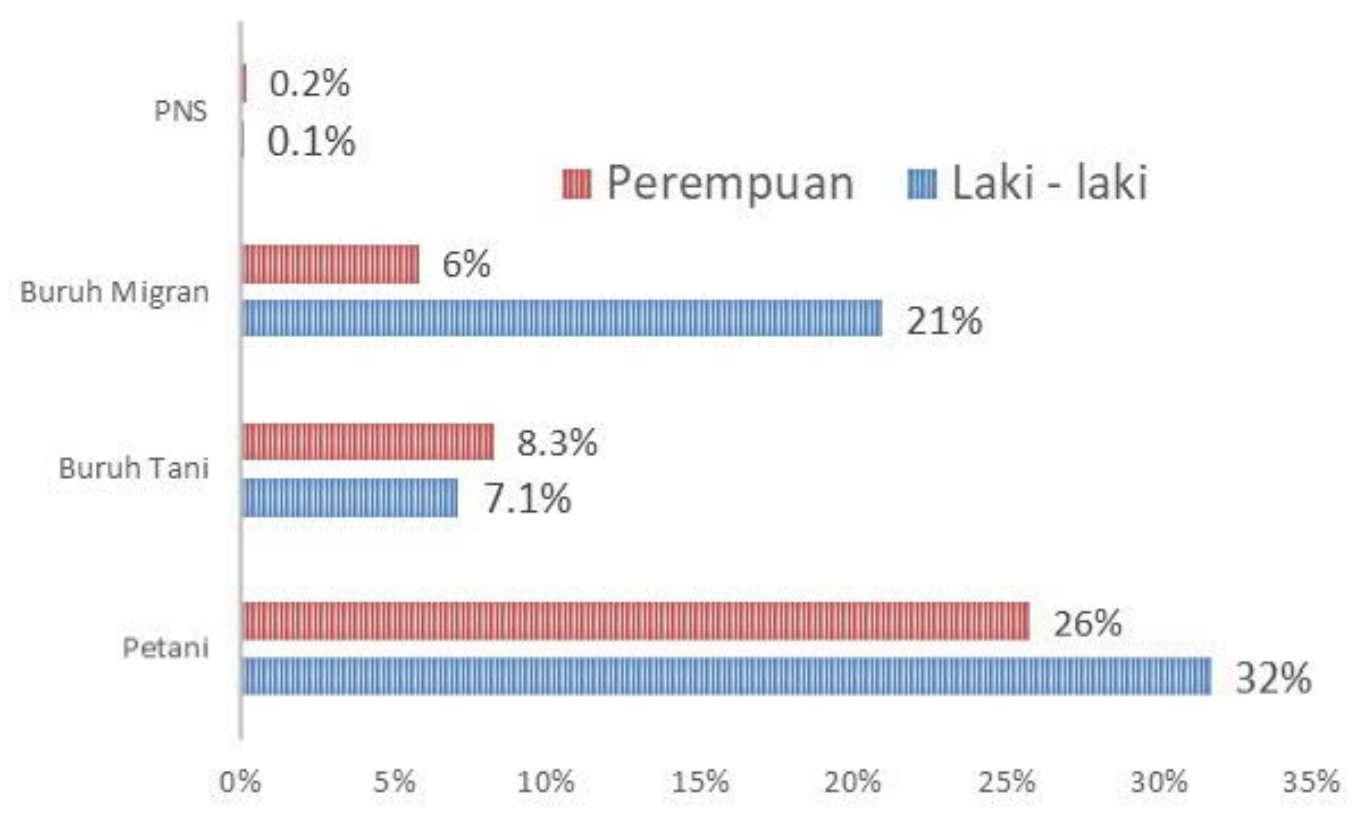

Gambar 4. Diagram Batang Mata Pencaharian Penduduk Desa Gedangan

Dengan adanya diagram batang, informasinya menjadi sangat ringkas, yaitu mata pencaharian penduduk yang dominan adalah petani dan buruh migran berdasarkan kategori penduduk laki-laki. Materi selanjutnya disampaikan melalui workshop dengan mendemokan proses pembuatan grafik dalam bentuk excel oleh narasumber. Dalam 
pengelolaan data kependudukan yang asli, perangkat desa akan diajarkan tentang penggunaan fungsi sort, filter, dan form pada manajemen data dalam program excel, serta materi workshop dengan menggunakan fungsi pivot tabel pada Ms. Excel beserta visualisasi datanya dengan menggunakan grafik yang sesuai skala pada data kependudukan. Pada kegiatan simulasi hasil workshop oleh narasumber, peserta yang mengalami kesulitan dalam penggunaan dan proses pengolahan data terutama pada penggunaan fungsi-fungsi manajemen data pada Ms. Excel juga dibantu oleh Tim Pengabdian Dosen Statistika dan mahasiswa Prodi Statistika sebagai asisten pelatihan sehingga kesulitan tersebut dapat terselesaikan.

Pelaksanaan kegiatan Program Pengabdian kepada Masyarakat oleh Tim Dosen Pengabdian Statistika Universitas PGRI Adi Buana Surabaya berjalan dengan lancar. Para peserta palatihan dari Desa Gedangan sangat antusias mengikuti setiap kegiatan yang sudah terjadwal. Kendala yang dihadapi saat pelaksanaan adalah lokasi yang digunakan pada kegiatan pelatihan terbuka, sehingga materi yang ditayangkan melalui proyektor tidak terlihat jelas dan lalu lalang orang yang berada di Balai Desa Gedangan mengganggu tampilan materi sehingga kosentrasi peserta pelatihan terganggu.

\section{salah benar}

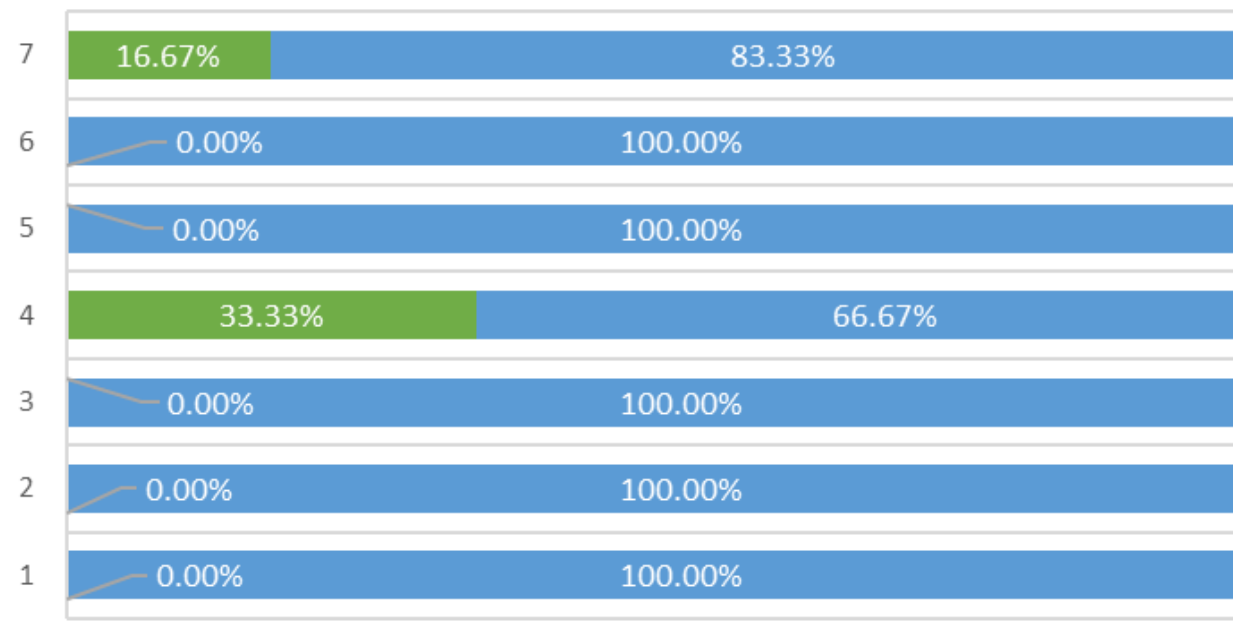

Gambar 5. Evaluasi Hasil Pelatihan Data Kependudukan

Gambar 5 adalah gambar evaluasi yang dilakukan untuk mengetahui seberapa dalam pemahaman peserta dari hasil pelatihan. Proses evaluasi dilakukan dengan memberikan soal yang berhubungan dengan materi grafik yang disampaikan. Pemahaman peserta diketahui dari persentase jawaban benar untuk setiap soal yang diberikan. Selain itu, 
terdapat dua soal yang menunjukkan persentase jawaban benar lebih besar dibanding jawaban yang salah. Secara keseluruhan, peserta telah memahami materi yang disampaikan dengan baik sehingga jawaban benar pada soal evaluasi yang diberikan setelah pelatihan lebih dominan dibanding jawaban salah.

Peserta pelatihan sangat antusias dalam mengikuti kegiatan. Hal ini terlihat dari jumlah pertanyaan yang disampaikan dan berhubungan dengan permasalahan yang dihadapi oleh peserta sesuai dengan materi pelatihan. Para peserta pelatihan berharap kegiatan ini tetap berjalan secara berkesinambungan karena program pengabdian ini sangat menunjang keterampilan dalam bidang keadministrasian sehingga lebih memudahkan peserta pelatihan dalam mengolah data kependudukan khsusnya pelaporan profil desa yang berpotensi.

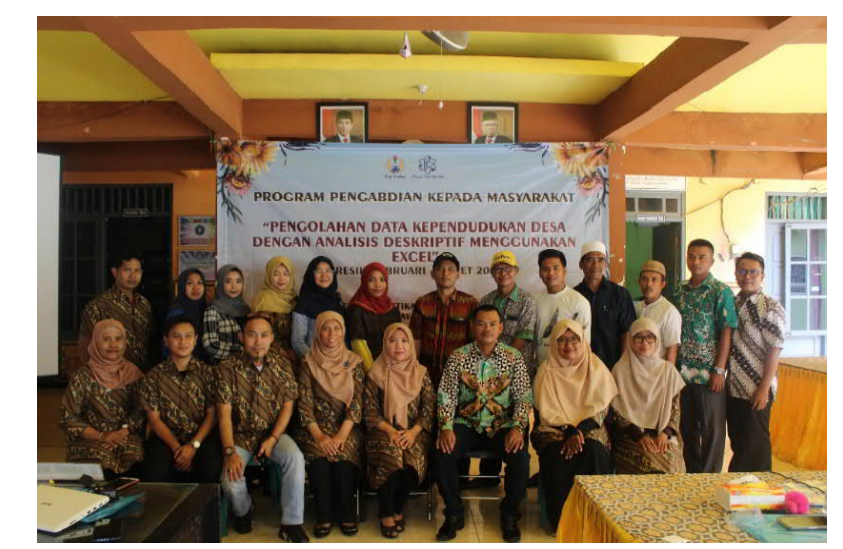

Gambar 6. Foto Bersama Tim Dosen dengan Pseserta Pelatihan

Kegiatan Pengabdian pada Masyarakat ditutup dengan doa dan kegiatan foto bersama. Seperti pada Gambar 6, kegiatan foto bersama dilakukan oleh Tim Pengabdian Dosen Statistika UNIPA Surabaya, Kepala Desa Gedangan, dan seluruh peserta pelatihan.

\section{SIMPULAN}

Berdasarakan hasil program pengabdian yang telah dilaksanakan dan ditinjau dari situasi selama pelatihan berlangsung dapat disimpulkan bahwa pelatihan ini berhasil karena kemampuan perangkat desa dan bumdes dalam mengolah data administrasi meningkat. Selain itu, keterampilan guru PAUD dalam mengolah data laporan penelitian menggunakan program Ms. Excel juga meningkat. Tidak hanya itu, keaktifan peserta saat workshop juga dapat dijadikan tolok ukur bahwa pelatihan yang diberikan memberikan pengaruh yang signifikan. Hal tersebut dapat dilihat dari antusias peserta yang tinggi selamat mengikuti pelatihan dan muncul berbagai pertanyaan yang berkaitan dengan materi pelatihan. 


\section{UCAPAN TERIMA KASIH}

Terimakasih kepada Universitas PGRI Adi Buana Surabaya yang telah memberikan dana dan mendukung serta memfasilitasi program pengabdian kepada masyarakat ini. Program pengabdian ini juga dapat berjalan lancar karena adanya kerjasama antara Tim Pengabdian Dosen Prodi Statistika dan Kepala Desa Gedangan Kab. Gresik.

\section{DAFTAR PUSTAKA}

Bhattacharyya, Gouri K. \& Richard A.Johnson. 2009. Statistical Principles And Methods (6 $6^{\text {th }}$ ed). United States: John Wiley \& Sons, Inc.

Creswell J. 2015. Riset Pendidikan Perencanaan Pelaksanaan dan Evaluasi Riset Kualitatif dan Kuantitatif. Yogyakarta: Pustaka pelajar.

Guerrero, H. 2019. Excel Data Analysis, Modeling and Simulation. ( $2^{\text {th }}$ ed). USA: Springer

Hidayat, W. \& Rahardjoo, N. 2014. Visualisasi Data Jumlah Penduduk dalam Bentuk Kartogram (Studi Kasus di Daerah Istimewa Yogyakarta). Jurnal Bumi Indonesia (pp 1-10). Yogyakarta : Univeritas Gajah Mada.

Heiberger, R.M. \& Holland, B. 2015. Statistical Analysis and Data Display, An Intermediate Course with Examples in R. (2 ${ }^{\text {th }}$ ed). London : Springer.
Patmawati, H. \& Santika, S. 2016. Penggunaan Software Microsoft Excel sebagai Alternatif Pengolahan Data Statistika Penelitian Mahasiswa Tingkat Akhir. Prosiding Seminar Nasional Matematika X. (pp 124-129). Semarang: Universitas Negeri Semarang.

Sahid. 2006. Analisis Data Statistiks dengan MS Excel. Laboratorium Komputer Jurdik Matematika FMIPA UNY.

Panjaitan, D. J., \& Firmansyah. 2018. Pelatihan Pengolahan Data Statistik dengan Menggunakan SPSS. Prossiding Seminar Nasional Hasil Pengabdian. (pp 38-45). Medan : Universitas Muslim Nusantara Al-Washlliyah. 